\title{
Factors that Influence Farmer's Behavior Towards Risk
}

\author{
Muhamad Nurdin Yusuf*, Agus Yuniawan Isyanto, and Sudradjat Sudradjat \\ Department of Agribusiness, Faculty of Agriculture, Galuh University, Jl. R. E. Martadinata No.150, \\ Ciamis 46274, Indonesia
}

\begin{abstract}
The research was carried out with the aim to find out the behavior of farmers towards risk and the factors that influence it. The research sample was 100 paddy farmers in flood-prone area paddy fields in Pangandaran District, West Java Province, Indonesia. Farmer's behavior towards risk was analyzed using quadratic utility functions, while the factors that influence farmer's behavior towards risk were analyzed using logistic regression. The results showed farmers 87 was risk neutral, while 13 farmer risk takers were farmers. Education, familys size and income significantly influence farmer's behavior towards risk; while age, experience, land area, production risk, price risk, income risk and group did not significantly influence farmer's behavior towards risk.
\end{abstract}

Keywords: Land area, logistic regression, risk taker, quadratic utility.

\section{Introduction}

The impact of global climate change has an effect on paddy production in Indonesia in the form of flooding which results in crop failure or a decrease in paddy production [1]. Climate change has occurred in Indonesia with indications of an increase in temperature and changes in rainfall patterns. Agriculture is very vulnerable to the effects of climate change with an indication of the high level of danger in decreasing paddy production as a result of increasing temperatures and changes in rainfall patterns. The average decline in paddy production is $1.37 \% \mathrm{yr}^{-1}$ which has the potential to cause a decline in national food production [2].

The threat of flooding in paddy fields can lead to reduced harvest area and paddy production [3]. Production is related to the nature of farming which is always dependent on nature supported by risk factors [4]. The risk of failure in farming comes from the use of new technology, prices of agricultural production, capital, government policies and individual behavior of farmers in dealing with outsiders [5], as well as climate change and weather that are not in accordance with crop needs [6]. The main risks farming include flooding [7].

Farmer's behavior towards risk consists of risk averter, risk neutral, and risk taker. Farmer behavior is the basis of farmers' decision making in carrying out their farming [1]. Farmer's behavior towards risk has an important role in influencing the productivity of agricultural products which has an impact on production efficiency [8]. Factors that

*Coresponding author: muhamadnurdinyusuf@gmail.com 
influence farmer behavior towards risk are the area of planting, age, education, experience, family size, income and productivity risk [8].

\section{Research methodology}

Amount ten villages in Padaherang and Kalipucang Subdistricts in Pangandaran District were taken purposively as a sample area with consideration of being areas that have flood-prone rice fields. From each village a sample of ten farmers was taken, so that the total number of samples was 100 farmers.

Farmer's behavior towards farming risk was analyzed using the quadratic utility Equation (1):

$$
U=\tau_{1}+\tau_{2} M+\tau_{3} M^{2}
$$

Where:

$\mathrm{U}$ : utility for expected income (in util)

$\tau_{1}:$ intercept

$\mathrm{M}$ : expected income at the balance point (rupiah value from certainty equivalent (CE)

$\tau_{2}:$ indifference income coefficient $(\mathrm{CE})$

$\tau_{3}:$ farmer risk coefficient

The risk preference coefficient shows the farmer's attitude to risk, namely:

$\tau_{3}=0:$ Risk neutral

$\tau_{3}<0$ : Risk averse

$\tau_{3}>0$ : Risk taker

The factors that influence farmers' behavior towards risk are analyzed using ordinal logit regression with the following Equation (2):

$$
P_{i}=F\left(Y_{i}\right)=F\left(\alpha+\beta_{1} X_{1}+\beta_{2} X_{2}+\beta_{3} X_{3}+\beta_{4} X_{4}+\beta_{5} X_{5}+\beta_{6} X_{6}+\beta_{8} D_{8}+\beta 9 D 9+\beta_{10} D\right)
$$

$\mathrm{Y}_{\mathrm{i}}$ values are calculated using the following Equation (3):

$$
Y_{i}=\log \left[P_{i} /\left(1-P_{i}\right)\right]=\left(\alpha+\beta_{1} X_{1}+\beta_{2} X_{2}+\beta_{3} X_{3}+\beta_{4} X_{4}+\beta_{5} X_{5}+\beta_{6} X_{6}+\beta_{7} X_{7}+\beta_{8} X_{8}+\beta_{9} X_{9+}\right.
$$

Where:

$\mathrm{Y}_{\mathrm{i}}=$ Opportunities for farmers to make decisions, where:

$\mathrm{Y}_{1}=1$ for the farmer who are risk averse

$Y_{2}=2$ for the farmer who are risk neutral

$\mathrm{Y}_{3}=3$ for the farmer who are risk taker

$\alpha=$ Intercept

$\beta_{\mathrm{i}}=$ Parameter regression coefficient $(\mathrm{i}=1,2,3, \ldots .10)$

$\mathrm{X}_{1}=$ Age (year)

$\mathrm{X}_{2}=$ Education (year)

$\mathrm{X}_{3}=$ Family size (person)

$\mathrm{X}_{4}=$ Experience (year)

$\mathrm{X}_{5}=$ Land area (ha)

$\mathrm{X}_{6}=$ Farm income (IDR)

$\mathrm{X}_{7}=$ Production risk

$\mathrm{X}_{8}=$ Price risk

$\mathrm{X}_{9}=$ Income risk

$\mathrm{D}=$ Membership in groups ( 1 if being a member of a group, 0 if not)

$\mathrm{e}=$ error term 


\section{Results and discussion}

\subsection{Farmer's behavior towards risk}

Farmer's behavior towards risk in paddy farming in flood-prone paddy fields can be seen in Table 1.

Table 1. Farmer's behavior towards risk

\begin{tabular}{|c|c|c|}
\hline Farmer's behavior towards risk & Number of people & Percentage \\
\hline Risk Neutral & 87 & 87.00 \\
\hline Risk Taker & 13 & 13.00 \\
\hline Total & 100 & 100.00 \\
\hline
\end{tabular}

Table 1 shows that most farmers $(87 \%)$ are risk neutral, while the rest $(13 \%)$ are risk takers. There are no risk averse farmers. According to [9], the absence of risk avers farmers show that there are no farmers who are willing to sacrifice their income or potential income to reduce opportunities for loss or low income. According to [1], farmers will try to avoid failure and not get big profits by taking risks. Such behavior is called safety first, which is characteristic of most farmers.

Farmers who are risk neutral are farmers who have a rational attitude in facing risks [9]. Risk neutral farmers tend to cultivate based on hereditary habits. They only seek income that can meet their family's needs [10]. If there is additional capital for risk neutral farmers, then they might add input to get higher income [11]. The availability of capital for farmers is a risk factor that is considered to affect farmers to the farming they are doing [12].

Risk taker farmers are farmers who are willing to allocate and use their production factors to the maximum, even though there are risks that must be faced with the aim of obtaining optimal results. [8] states that conceptually farmers are able to reduce production risk and price risk by improving their productivity, the use of diversification, the use of appropriate cropping patterns, strengthening farmer institutions, and bargaining position of farmers can increase farmers' production and income [7].

\subsection{Factors that influence farmer's behavior toward risk}

The results of the analysis of factors that influence farmer behavior on risk in paddy farming in flood-prone paddy fields can be seen in Table 2 .

Table 2. Factors that influence farmer's behavior towards risk

\begin{tabular}{|l|c|c|c|}
\hline Variabel & B & Wald & $\operatorname{Exp(B)}$ \\
\hline Age & 0.788 & 0.020 & 2.199 \\
\hline Education & 7.139 & $3.452^{* *}$ & $1.260 \mathrm{E} 3$ \\
\hline Family size & 4.983 & $4.303^{*}$ & 145.958 \\
\hline Experience & -0.149 & 0.003 & 0.861 \\
\hline Land area & 0.687 & 0.279 & 1.988 \\
\hline Farm income & 2.896 & $4.313^{*}$ & 18.103 \\
\hline
\end{tabular}

(Continued on next page) 
Table 2. Continued

\begin{tabular}{|l|c|c|c|}
\hline Variabel & B & Wald & $\operatorname{Exp(B)}$ \\
\hline Production risk & 1.029 & 0.407 & 2.799 \\
\hline Price risk & -0.834 & 1.016 & 0.434 \\
\hline Income risk & -0.134 & 0.014 & 0.875 \\
\hline Group & 1.795 & 0.946 & 6.020 \\
\hline Constant & -69.854 & $3.703^{* *}$ & 0.000 \\
\hline \multicolumn{4}{|c|}{ Model Summary } \\
\hline -2 Log likelihood & Cox \& Snell R Square & Nagelkerke R Square & Chi-square \\
\hline \multicolumn{2}{|c|}{0.441} & 0.819 & $18.307^{*}$ \\
\hline,$* *=$ significant at 5\% $\%$ 10 \%
\end{tabular}

Table 2 shows that age is not significant influence farmers' behavior towards risk. This shows that the difference in age of farmers does not affect the behavior of farmers in dealing with risk. Education significantly influences farmer's behavior towards risk. The results of this study are in accordance with the results of research from [13]. The higher the level of education of farmers, the more courageous farmers face risks [5, 7]. According to [13], the level of education of farmers who are still low makes the main cause of the majority of farmers who choose safety first (zero risk) behavior in developing their farming.

Family size significantly influences farmer's behavior towards risk. The results of this study are in accordance with the results of research by [14]. According to [9], family size affects the outpouring of time that can be allocated for farming. According to [14], the more number of members of the farmer's family, the higher the capacity of the workforce owned by the farmer in facing the risk.

Experience does not significantly influence farmers' behavior towards risk. The longer the farmer's experience, the more careful it will be in carrying out farming so that it tends to be more neutral to risk. The results of this study are in accordance with the results of research from [7].

Land area does not significantly affect farmer's behavior to risk. The results of this study are consistent with the results of a study from [5] which shows that the addition or reduction of land area will not reduce risk aversion or that farmers are neutral towards risk.

Revenue significantly influences farmer's behavior towards risk. The greater the income the farmer receives from the farming that is carried out, the farmer will be more courageous in accepting the risk. The results of this study are in accordance with the results of research from $[8,14,5]$. According to [8], the higher the farm income received by farmers, the farmers will be more willing to accept the risk.

Production risk does not significantly influence farmer's behavior towards risk. According to [7], the magnitude of the risk of production faced by farmers due to the uncertainty of results as a result of natural factors and income as a result of price fluctuations, causes farmers to tend to reject the possibility of accepting the risks and uncertainties of the business. According to [15], efforts to handle production risk can be done by implementing a diversification and agricultural insurance program.

Price risk does not significantly influence farmer's behavior towards risk. According to [16], farmers' household attitudes in carrying out production activities can be seen from variations in prices as a measure of price risk. According to [17], the behavior of farmers who accept price risk is caused by the expectation of expected price reductions compared to the actual prices that make farmers continue to carry out farming as long as they provide benefits. According to [18], the behavior of farmers does not dare to risk due to fluctuations 
in production and selling prices which will have an impact on farmers' income.

Income risk does not significantly influence farmer behavior towards risk. The higher the income risk faced by farmers, the more farmers will behave neutrally against risk. Membership in groups does not significantly influence farmers' behavior towards risk. According to [19], group membership is one of the efforts of farmers to reduce the risk of farming by cooperating with each other, exchanging information in managing their farming with fellow farmers.

\section{Conclusion}

Amount 87 farmers are risk neutral and 13 farmers are risk takers. Education, family size and income significantly influence farmer's behavior towards risk; while age, experience, land area, production risk, price risk, income risk and group did not significantly influence farmer's behavior towards risk.

\section{References}

1. C. Gardebroek, M.D. Chavez, A.O. Lansink, J. Agric. Econ. 61,1:60-75(2010). https://doi.org/10.1111/j.1477-9552.2009.00222.x

2. Ruminta, Handoko, T. Nurmala. Jurnal Agro. 5,1:48-60(2018). [in Bahasa Indonesia]. https://journal.uinsgd.ac.id/index.php/ja/article/download/1607/pdf_16

3. Shahab. E. Saqib, Mokbul. M. Ahmad, Sanaullah. P, Irfan. A Rana, Int. J. Disaster Risk Reduc. 18:107-114(2016).

https://www.researchgate.net/profile/Shahab_E_Saqib/publication/304305997_An_Em pirical_Assessment_of_Farmers\%27_Risk_Attitudes_in_Flood-Prone_Areas_of_Pakis tan/links/5bf55cd2299bf1124fe32898/An-Empirical-Assessment-of-Farmers-Risk-Attit udes-in-Flood-Prone-Areas-of-Pakistan.pdf?origin=publication_detail

4. C. Gardebroek, Eur. Rev. Agric. Econ. 33,4:485-510(2006). https://doi.org/10.1093/erae/jbl029

5. M.P. Lucas, I.M. Pabuayon., Asian J. Agric. Dev. 8,2:61-77(2011). https://tind-customer-agecon.s3.amazonaws.com/9fdd6f1e-7e97-4413-a5f2-ffb38a8fea 0c?response-content-disposition=attachment $\% 3 \mathrm{~B} \% 20$ filename $\% 2 \mathrm{~A} \% 3 \mathrm{DUTF}-8 \% 27 \%$ 27AJAD_2011_8_2_5Lucas.pdf\&response-content-type=application $\% 2 F p d f \& X-A m z-$ Algorithm=AWS4-HMAC-SHA256\&X-Amz-Expires $=86400 \& X-A m z-C r e d e n t i a l=A K$ IAXL7W7Q3XHXDVDQYS\%2F20200908\%2Feu-west-1\%2Fs3\%2Faws4_request\& $\underline{X-A m z-S i g n e d H e a d e r s}=$ host $\& X-A m z-D a t e=20200908 T 165030 Z \& X-A m z-$ Signature $=$ 20ca172c04b02c087149aa1ba32cc86309bf574faede65f1910b98ade0e76e34

6. T. Tiedemann, U.L. Lohman, J. Agric. Econ. 64,1:73-96(2012). https://doi.org/10.1111/j.1477-9552.2012.00364.x

7. J.N. Nmadu, G.P. Eze, A.J. Jirgi. British J. Econ. Manag. Trade, 2,2:92-108(2012). https://www.journaljemt.com/index.php/JEMT/article/download/30022/56339

8. R. Darma, T.N.A. Rahmadanih, R. Amandaria. Int. J. Agric. Syst. 2,1:77-89(2014). http://pasca.unhas.ac.id/ojs/index.php/ijas/article/download/24/23

9. E.D. Oruonye, IJFSE. 3,4:113-117(2013). http://www.ijfse.com/uploadedfiles/IJFSEArchive/IJFSE2013/3(4)/01.pdf

10. M.C. Plaxedes, P. Mafongoya, Clim. Risk Manag. 16:145-163(2017). https://doi.org/10.1016/j.crm.2017.02.001 
11. Y. Ferrianta, M.F. Makki, Suprijanto, Rifiana. Int. J. Agric. Manag. Dev. 5,2:133-139(2014).

https://www.researchgate.net/publication/272667859_Risk_Analysis_and_Strategy_of _Rice_Farmers_in_Swampland_in the Face_of_Climate_Change_Impact_Case_in_S outh_Kalimantan_Province-Indonesia/fulltext/57a79def08aee07544c1d003/Risk-Analy sis-and-Strategy-of-Rice-Farmers-in-Swampland-in-the-Face-of-Climate-Change-Impa ct-Case-in-South-Kalimantan-Province-Indonesia.pdf?origin=publication_detail

12. A.D. Brauw, P. Eozenou. J. Dev. Econ. 111:61-74(2014). https://www.researchgate.net/profile/Patrick_Eozenou/publication/266617635_Measuri ng_risk_attitudes_among_Mozambican_farmers/links/5435ad990cf2643ab9867e0d/M easuring-risk-attitudes-among-Mozambican-farmers.pdf?origin=publication_detail

13. C.A. Kalu, J.A. Mbanasor. NAPReJ, 1,1:1-10(2016).

https://econpapers.repec.org/scripts/redir.pf?u=https\%3A\%2F\%2Fdoi.org\%2F10.2200 4\%252Fag.econ.292052; $\mathrm{h}=$ repec:ags:naprej:292052

14. M.M. Haque, S. Bremer, S. Aziz, J.P. Sluijs, Clim. Risk Manag. 16:43-58(2017). https://dx.doi.org/10.1016/j.crm.2016.12.002

15. S. Dadzie, N. Kwesi, H. de Graft. A, Int. J. Agric. For. 2,2:29-37(2012). https://www.researchgate.net/profile/Samuel_Dadzie/publication/241699647_Attitudes _Toward_Risk_and_Coping_Responses_The_Case_of_Food_Crop_Farmers_at_Agona Duakwa_in_Agona_East_District_of_Ghana/links/0046351caa436af152000000/Attit udes-Toward-Risk-and-Coping-Responses-The-Case-of-Food-Crop-Farmers-at-AgonaDuakwa-in-Agona-East-District-of-Ghana.pdf?origin=publication_detail

16. S.R. Fajri, E. Fauziyah. J. Hort. Indonesia, 9,3:188-196(2018). [in Bahasa Indonesia] https://journal.ipb.ac.id/index.php/jhi/article/download/26496/17128/

17. C. Mulwa, P. Marenya, D.B. Rahut, M. Kassie, Clim. Risk Manag. 16:208-221(2017). https://reader.elsevier.com/reader/sd/pii/S2212096317300062?token=8C6D3F91A4BE F28A0A8335A476A7B6B75EB4D84ED7742D9C358F0465D68675FD002D8C4A37 1BC054A01FAF3CD18289A8

18. A. Ali, O. Erenstein, Clim. Risk Manag. 16:1-12(2017).

https://www.researchgate.net/profile/Olaf_Erenstein/publication/311879490_Assessing _farmer_use_of_climate_change_adaptation_practices_and_impacts_on_food_security _and_poverty_in_Pakistan/links/58b71affaca27261e51a4134/Assessing-farmer-use-ofclimate-change-adaptation-practices-and-impacts-on-food-security-and-poverty-in-Pak istan.pdf?origin=publication_detail

19. A. Tripathi, A.K. Mishra. Clim. Risk Manag. 16:1-37(2017).

https://www.researchgate.net/publication/310815962_Knowledge_And_Passive_Adapt ation_to_Climate_Change_an_Example_From_Indian_Farmers/fulltext/583a4d6308ae 3a74b49ea7e4/Knowledge-And-Passive-Adaptation-to-Climate-Change-an-Example-F rom-Indian-Farmers.pdf?origin=publication_detail 